\title{
1.1. MANAGING EMPLOYMENT IN PROCESS OF RESTRUCTURING ENTERPRISES
}

\section{Summary}

The aim of the herein paper is to present the theoretical conditioning of employment in the processes of restructuring enterprises. The author describes the significance of the human factor in the process of organizational change. The preparation of a personnel strategy that is strongly integrated with the general strategy of an enterprise is a fundamental element in the management of human resources in a restructured enterprise. On the basis of the personnel strategy adopted, it is possible to prepare a social plan of restructuring in which propositions of change should be included in the area of the employment of workers remaining in the enterprise and those leaving. Great significance is attached to the problem of the adaptation of employees to the new organizational conditions. For the adaptation to be rapid and effective, the management is required to build the policy of reconversion where the perception of the employee as human capital would be of importance thanks to which it is possible to compete with other enterprises. In the process of restructuring in enterprises, partnership culture that is associated with organizational identification may be useful in which, mutual cooperation exists between the management of the company and the employees. This culture is based on the feeling of involvement, solidarity, trust and interdependence. Mutual partnership ties are the basis of the success of an enterprise.

Keywords: enterprise, restructuring, employment, human resources, organizational culture

\section{Introduction}

In today's market economy enterprises are forced to adjust to the constantly changing external environs, which in turn leads to the implementation of organizational change. This sometimes takes on the form of restructuring which is defined as a well thought-out reorientation of aims (mission) of an enterprise that are adequate to the existing or forthcoming changes in the environs in the future, while also adjustment of techniques, organization, economics and personnel to the aforesaid changes (Nalepka, 1998) Restructuring relates to assets, capital, employment, as well as organization and ownership structures (Kożuch, 2010).

In the process of restructuring, those managing the enterprise concentrate to a large extent on the aims associated with finances, whereby activities in this area are to improve the standing of the enterprise and its cash flow. Nevertheless, it is not possible to avoid the social aspect of restructuring, as the changes occurring in the 
sphere of personnel management are the most visible. The process of restructuring frequently comes down to the reduction of the general number of those employed, which is equated to the decrease in the level of labour costs (Oleksyn, 2000). As illustrated by empirical research in Poland, in the period of crisis enterprises carrying out restructuring pursue the reduction of the work timespan, reduction of remuneration and reduction of employment levels (Chodorek, 2010. Restructuring employment levels should not be merely a reduction of the personnel as it also provides the opportunity of increasing the effectiveness of the employed workers. In a restructured enterprise, a significant task for the managerial staff is the building of the strategy of employment that facilitates the realization of rational employment in an enterprise in the period of change (Illés et al., 2015).

The aim of the herein paper is to present the theoretical conditioning of employment in the process of managing employment in the processes of restructuring enterprises. The research method that has been applied is the method of critical analysis of subject-related literature.

\section{Essence of restructuring of employment in an enterprise}

In subject-related literature the restructuring of employment is defined as a set of activities adjusting the state and structure of the employed personnel to the prevailing conditions rendering the realization of the aims of an enterprise possible (Lachiewicz et al., 2005). Simultaneously, this not only refers to the reduction of employment levels with the aim of restricting the costs of activities, but also adjusting the number of employees to the current needs and strategies of the enterprises at hand. The fundamental activities associated with the restructuring of employment may enumerate the following: (Czekaj, Zakrzewska-Bielawska, 2006);

- Rationalization of the structure of employment in an organizational and occupational structure;

- Changes in the level and nature of qualifications leading to growth in terms of the competences held by employees that are required for the new needs of the organization;

- Changes in the structure of employment in accordance with age and seniority, thus leading to the rejuvenation of working staff, or to the creation of preferences for the specific types of professional experience;

- Improvement of the processes of personnel management such as the following: recruitment and selection, internal recruitment for specific types of work positions and systems of employee training;

- Adjustment of the motivational systems to the changed conditions of the functioning of an enterprise, e.g. new ways of motivating employees associated with the requirements of labour efficiency;

- Changes in the principles of the management of working time of personnel by means of implementing flexible forms of working time.

Hence, it is possible to acknowledge that the restructuring of employment is not associated with only the reduction of the personnel employed, but also relates to the 
issue of employee transfers associated with new tasks, promotions and retraining associated with the pursuit of increasing labour quality and efficiency.

Restructuring of employment may adopt two forms as follows: corrective and development actions (Czekaj, Zakrzewska-Bielawska, 2006). The first form is connected with the pursuit of the achievement of clear and fast economic effects by means of the radical reduction of employees in the mode of individual and grouped redundancies. This usually occurs together with corrective actions associated with other areas of the functioning of enterprises, e.g. discarding the surplus fixed assets. In turn, developmental restructuring is aimed at the comprehensive and long-term activities associated with adjusting the magnitude and structure of employment to the strategies of an enterprise. This is connected with building long-term plans for the development of human resources, together with ensuring the possibilities of the realization of the individual paths of development for employees. In terms of the long-term perspective of the activities of an enterprise, developmental restructuring is significant, whereby it favours the development of an enterprise and improves its market situation.

Restructuring is a process that requires precise preparation as it is associated with, among others, the risk of the lack of acceptance of change on the part of employees, while also the risk of qualified staff leaving. One of the stages of restructuring is the preparation of a plan. Elements of this plan should be as follows: diagnosis of the current state of employment and the hitherto level of its effectiveness in the context of both internal and external requirements, namely, the market environment, evaluation of the state of employment and predictions of the personnel needs; specification and acquisition of the necessary resources for restructuring, making changes in terms of employment from the viewpoint of the transformation into other areas of activities, implementation of strategic and operational functions of planning employment, as well as carrying out qualitative transformation in terms of managing human resources (Sajkiewicz, Sajkiewicz 2002). The plan of restructuring should be connected with the personnel strategy and social plan minimizing the reluctance of employees towards changes.

\section{Personnel strategy as an element of the process of restructuring of employment}

The first stage of managing employment in the process of restructuring is the preparation of the personnel strategy that may be perceived as a long-term concept relating to employee resources leading to their appropriate formation and involvement with the aim of supporting the enterprise in terms of attaining market success (Listwan, 2006). Its aim is to define the directions and ways of utilizing human resources in the pursuit of achieving the aims of the enterprise itself. Creating the personnel strategy comes down to the constant improvement of the particular elements of human potential with the aim of adjusting them to the emerging changes within the enterprises and its environs (Pocztowski, 1998). In formulating the personnel strategy, the management of the enterprises is in search of the answers to the following questions: 
- What is the state of the enterprise in terms of human resources?

- What state of employment do we assume to attain over a specified long-term period?

- What methods are we to avail of to achieve this level?

One of the elements of the personnel strategy is the personnel plan which fulfils a multitude of functions. Firstly, it signifies the prediction of the necessary number of employees over a specified time scale and location with the appropriate qualifications and modifications to the state and structure of employment, as well as the mutual subjection of the employees to the particular organizational cells and work positions (Pocztowski 1998). Secondly, the personnel plan is correlated with information about future personnel changes on the internal labour market, together with information flowing in from the external market and labour law (Oechler, 2000). Thirdly, personnel planning is integrated with other plans within the enterprise, e.g. with the investment plan. Hence, the personnel plan should contain methods and means of the professional adaptation of the employees remaining in the company, as well as taking account of the future personnel needs arising from investment programs.

Personnel planning in an enterprise encompasses such areas of planning as the following: planning personnel needs, planning personnel equipment, planning staff redundancies, planning staffing, planning personnel development and planning personnel costs (Oechler 2000). The focal point in the planning of human resources is the plan of personnel needs that prepares the tasks arising from the other partial plans of the company (e.g. investment plan) and the specification of the qualitative aspects, time and location of demand. The principal aim of the analysis of personnel needs is the specification of the desired number of employees of specified qualifications that are essential to the realization of the planned program of activities of the enterprise. Information stems from the plan of personnel needs with regard to future changes in the state and structure of the existing employment levels (Fehér, 2015).

A significant aspect of personnel planning lies with the planning of personnel positions. The aim of this planning is to subject the employed personnel to the existing organizational cells, work positions and activities. The basic functions of this plan are as follows: minimization of the costs arising from the optimization of the subjection of the work positions and employees on the basis of the established economic criteria and the maximization of the usefulness of employees for the execution of tasks in the specified work position (Pocztowski, 1998). A staffing plan of work positions provides the possibility of establishing the staff of employees that have potential in the sphere of increasing their professional efficiency which may be availed of in the future for taking on higher positions.

A staffing plan of work positions is integrated with the plan of personnel development. The principal aim of personnel development is the improvement of the potential of the work of individual employees with the aim of adjusting them to the changes occurring in an enterprise and its environs. During the course of building the plan of personnel development a list of questions to be answered is useful (Wagner, 1994): 
- What shall be the tasks and requirements with regard to employees in the future?

- How do the abilities and development potential of an employee look?

- Who should train?

- What is the demand for a specified type of qualification of employees?

- What is the budget at the disposal of the firm?

- Who may and who should take the managerial positions?

- What should be done in order for the transfer of an employee to a higher position in the structure of authority to be safe?

The answers to these questions facilitate the establishment of the quantitative and qualitative frameworks of the groups of employees that shall be taken into consideration in terms of the nominations for the managerial positions. Career paths are created for this group, which are one of the most important composite elements in the plan of personnel development.

Planning in the area of human resources also includes a plan for the reduction of employees arising from for instance, the changes in the competitive environs of the company. The management, by means of entering a social agreement with the representatives of the employee team may reduce the specified number of work positions that have ceased to be necessary in the enterprise.

In the case of planning employment in a restructured enterprise, we are faced with the dilemma of whether to lay off older employees and employ younger and better educated ones with higher qualifications to take their place, or rather propose the retraining of the employees hitherto employed in the company. The choice of the course of action is very important as it is associated with the adoption of the specific strategies of actions and specific social and economic costs. The second solution is supported by moral and social aspects, however the first solution is more favourable from an economic viewpoint.

Planning the state of employment is a difficult task which is what a manager is faced with, but which also brings tangible benefits. The benefit of planning human resources is first and foremost the optimal use of employees and the transparency of the processes occurring in the enterprise, while secondly it facilitates the definition of the needs in terms of the numbers and competences of employees, as well as the undertaking of action in advance in order to satisfy these needs and thirdly, it creates the perspectives of professional development for active employees.

\section{Social plan of restructuring of employment}

Restructuring in the social sense is perceived as the process of making people redundant and with relation to this fact, the reluctance of employees with regard to the proposed changes arises. With the aim of minimizing the reluctance of employees, a social plan should be created relating to the changes in the area of the employment of the workers remaining in the enterprise and those departing. The essence of the social plan is to ease the effects of the transformation in the area of human resources. The content of the social plan may encompass the following 
issues: problems and threats associated with the implementation of change; the proposed ways and means aimed at resolving these problems and threats; the identification of employees included in the plan, as well as the adopted criteria and means of their identification; the system and methods of aid in terms of the preparation by employees of their individual professional balance; the policy of reconversion encompassing the program of adaptation of employees to the changed conditions (Egeman, 2000). Thus, a social plan should on the one hand, contain the methods of professional adaptation of the employees remaining in the enterprise in terms of the new working conditions, while on the other hand, the means of aid for the employees made redundant.

The most important section of the social plan is the adaptation of the employees to the changes evoked by the process of restructuring. The process of adaptation signifies the adjustment of an individual to activities in a specific tangible and social environment. In the case of social and occupational adaptation, we are referring to the processes by which an employee adjusts to his/her workplace, namely: to the spaces, equipment and location in the natural environment; type of production or service; system and nature of work; methods of management and the existing social ties; the system of tangible and intangible incentives; social and living conditions, etc. (Sztumski, 1999). This process involves the formation and development of the essential competences of the employees, namely their knowledge, skills, experience and attitudes in the new conditions (Bahrami et al, 2016).

Adaptation in the processes of restructuring may take on the following forms (Czekaj, Zakrzycka-Bielawska, 2006):

- Re-grouping, namely professional adaptation involving the re-hiring of a worker for a work position similar to the hitherto position held;

- Retraining, namely adaptation involving the employment of a worker for a work position that significantly differs from the hitherto position held, which requires new qualifications and competences.

The process of adaptation of employees to the new conditions shall conclude successfully when the aim of the organization has been achieved, namely when an employee becomes familiar with the tasks involved and shall execute them successfully and shall identify with the aims of the enterprise and the values of the organizational culture (Kieser et al,. 1990, Hurta and Dunay, 2013).

With the aim of streamlining the process of adaptation of an employee to the new working conditions, the following questions may be of use:

- What does an employee expect from the new work position or from the enterprise?

- What do the future co-workers expect from the newly-recruited worker?

- What do the superiors (personnel manager / direct superior) expect from the new employee?

- What information does a new employee need in the new workplace?

In the process of adaptation of an employee to the new working conditions, a significant tool that streamlines this process is the individual plan of implementation for the new workplace, in which the joint discussions with the superior relating to 
the difficulties and problems of adapting for the employee to the new working conditions are taken into account.

The social plan of restructuring also includes activities on behalf of the employees made redundant. It would seem that the most appropriate practice with regard to the good of the employee is that of outplacement, which is a planned program of employee redundancies that is aimed at easing the new occupational and living situation for these employees (Małachowski, 2006). In practice, this occurs in the form of active support for people made redundant from their hitherto workplaces by means of providing aid in terms of finding new jobs, as well as training and information about the local labour market, assistance in terms of retraining, as well as psychological and legal support (Barcik, Dziwiński, 2016). Research on Polish enterprises indicates that it is most frequently executed in large enterprises. This is the result of among other things, a more developed organizational culture, as well as the awareness of how important the research on public relations is and how important the image of the enterprise is in its own internal and external environments (Jasińska, 2010).

\section{Partnership organizational culture as a factor supporting the process of restructuring of employment}

The implementation of the program of restructuring in an enterprise is the realization of two fundamental aims as follows: maintaining the organization on the market and leading to the achievement of profit. In order for the aims of the enterprise to be achieved, it must on the one hand adapt to the variable market conditions, while on the other hand minimize the resistance of the employees towards the organizational change. This aspect may be aided by the partnership organizational culture that supports the process of adjusting the employees to the changed working conditions. This is based on trust, responsibility, self-initiative and creativity. The basis of such an organizational culture is the employer-employee relation, thanks to which responsibility, cooperation and the community of interests are formed. The shape of these ties is influenced by the participation of the employees in the internal processes of information, communication and decision taking (Beyer et al., p.19). In the model of partnership organizational culture, an employer delegates some of his/her authority to the employees by acknowledging that this is the best alternative for the development of the enterprise. In return, he/she expects involvement and responsibility from the employees. Nevertheless, the employer participates in the decision making processes in the enterprise as he/she has a vested interest in such, namely he/she shall not lose his/her position as a result of the process of reorganization, yet in addition to this shall gain the opportunity of individual growth. In both cases, the conditions are of mutual trust and mutual interdependence. When these conditions are fulfilled, the mutuality of interests occurs and the partnership organizational culture is formed.

Including employees in the decision making process is an action aimed at informing the employees better in terms of the organization and increasing their level of 
involvement in its matters. The initiative lies with the employer, who provides the employees with the opportunity of active participation in the life of the organization. By implementing this, he/she assumes that the employees have huge potential that is unavailed of, but the managers retain the right to manage. The process of including employees in the life of the organization may take on the form of participation, which may be defined as the impact of the employees on a wide spectrum of issues associated with the organization, work, as well as the principles and conditions of work that involve deliberations and negotiations (Amstrong, 1998).

Employee participation mainly arises from instrumental motives. The management acknowledges that it is a very good medium for strengthening, as well as engaging and motivating the employees in order for them to realize his/her policies (Moerel, 1995). The attainment of a common understanding in terms of the scope of the employee participation, which is binding for both sides, should be documented in written form. The written declaration of cooperation constitutes the basis of common activities (Beyer et al., 1994).

Nevertheless, it is necessary to emphasize the fact that the partnership culture of an organization in contrast to employee participation does not only arise from economic premises, but also from moral premises based on basic values: justice and equality. Partnership culture is the realization of the vision of an enterprise that is oriented towards its employees. Partnership ties between on the one hand, the employer, while on the other hand the employee, require building trust, cooperation and the community of interests. The employees are expected to provide their creativity and personal involvement on behalf of the enterprise. Simultaneously, the employer must contribute in terms of building partnership ties by means of allowing employees to participate in the information and decision making processes.

An example that illustrates the significance of partnership culture in the process of restructuring is that of the company Farben $\mathrm{GmbH}$, which operates in the chemical sector on the domestic market of Germany and international markets (Bertelsmann Stiftung, 2000). In the 1990s, the company fell into crisis after a period of growth in terms of the sale of their products. This was the consequence of a fall in the profitability of the investment in the sector of paint and the lack of a long-term strategy of development. The high personnel and social costs in comparison with competitors were not possible to sustain over a long period of time and action had to be undertaken to restrict them. By way of consequence, the management took the decision to reduce the personnel by a total of 800 employees. The loss of such significant human capital and part of the market forced the enterprise to reorient its activities. This meant the reconstruction process in the company in favour of policies geared towards the market and the competition. In this process, an important role was played by the emphasis on the partnership ties between the employer and the employee. These were featured by openness in terms of communication and informing of the aims of the reconstruction process and the subsequent stages of reorganization. Trusted representatives and the management of the company actively participated in this process, who by means of direct contact with the employees alleviated their fears in terms of the future and indicated the benefits associated with the changes, namely the opportunities for the company and the employees in terms 
of development. Thanks to these actions, the employees changed their attitude to the enterprise. The perception of it as a good workplace with large perspectives of development became prevalent and the employees became its ambassadors on the local environs, which was a new and positive experience for a multitude of employees.

The partnership culture of the organization also shaped the communication between the managers and the employees which took on the form of partnership talks. This model of communication was practiced by the blue-collar workers right up to the general manager and became an element in the achievement of common aims.

The institutionalized form of mutual ties of the employees with the management of the firm was the creation of the position of co-manager that was taken by a representative of the employees working on behalf of their interests. Understanding and the cooperative attitude of the management of the enterprise, as well as the constructive strengthening of the interests of employees have become the basis of the success of the company Farben $\mathrm{GmbH}$. At present, the enterprise is indicated as a positive example of the achievement of success by means of the realization of the process of the sanctions of the company with the understanding and cooperation of the employees.

\section{Conclusions}

Restructuring of employment in an enterprise constitutes an intricate process, in which it is necessary to take account of the individual features of an employee and his/her attitude to the enterprise. The process of restructuring employment may only be accepted by the employees when it ensures the fulfilment of their needs and leads to their development. In order for an enterprise to be able to realize these intentions, it should prepare a plan of restructuring, in which a realistic and credible vision of the future of the firm is stipulated (medium-term and long-term effects, as well as "the price to pay"). In this plan, the plan of social restructuring is of great importance. The aim of this plan is on the one hand, the conviction and mobilization of employees to make this vision a reality, while on the other hand, rendering the specification of the target number and competences of employees that are necessary for the realization of the vision of the enterprise. In practice, conflict situations frequently occur that are the result of accepting the social plan in which propositions of large reductions of employees are stipulated and the lack of aid for the employees made redundant in terms of the search for new work. Such practices evoke protests that end up as strike actions. In order to avoid such situations, the management of the restructuring enterprise should help the people made redundant in tandem with the local authorities in terms of finding new employment, e.g. by means of organizing training that facilitates the retraining of the people made redundant, or training courses to help them adjust to the new conditions. 


\section{References}

1. Amstrong, M. (1998): Zarządzanie zasobami ludzkimi (Management of human resources). Kraków: Wydawnictwo Profesjonalnej Szkoły Biznesu.

2. Bahrami, P., Nosratabadi, S., Illés B. Cs. (2016): Effects of intellectual capital components on corporate entrepreneurship. pp. 27-34. In: Okreglicka M, Gorzen-Mitka I, Lemanska-Majdzik A, Sipa M, Skibinski A (eds.) Proceedings of the 1th International Conference Contemporary Issues in the Theory and Practice of Management 2016. 479 p. Wydawnictwo Politechniki Czestochowskiej, Czestochowa

3. Barcik, R., Dziwiński P. (2016): Społecznie odpowiedzialna restrukturyzacja zatrudnienia (Socially responsible restructuring of employment). Imperatyw przedsiębiorczości a odpowiedzialność przedsiębiorcy (Imperative of entrepreneurship and responsibility of entrepreneur), PRACE NAUKOWE Uniwersytetu Ekonomicznego we Wrocławiu nr 419, Wrocław: Wyd. Uniwersytet Ekonimczny we Wrocławiu. pp.21-32.

4. Beyer, H., Fehr, U., Nutzinger, H.G. (1994): Vorteil Unternehmenskultur: partnerschaftlischen handeln - den Erfolg mitbestimmen. Gütersloh: Verlag Betelsmann Stiftung.

5. Bertelsmann Stiftung (ed.) 2000: Systematische Beschäftigungs - Management in der Praxis: Kosten senken - Beschäftigung sichern. Gütersloh: Verl. Bertelmann Stiffung.

6. Chodorek, M. (2010) Przejawy globalnej recesji gospodarczej w polskich przedsiębiorstwach (Symptoms of global recession in Polish enterprises). Studia i Prace Kolegium Zarządzania i Finansów, nr 99, Warszawa: Szkoła Główna Handlowa, pp. 26-34.

7. Czekaj, J., Zakrzewska- Bielawska, A. (2006): Benchmarking jako metoda restrukturyzacji zatrudnienia $\mathrm{w}$ przedsiębiorstwie (Benchmarking as a method of restructuring employment in an enterprise). Zeszyty Naukowe Akademii Ekonomicznej w Krakowie, nr 713, pp. 37- 70.

8. Egeman, M.E. (2000): Restrukturyzacja przedsiębiorstwa i budowa strategii zatrudnienia (Restructuring of enterprises and building strategy of employment). In: Ludwiczyński A. [ed.] Strategiczne zarządzanie zasobami ludzkimi (Strategic management of human resources). Warszawa: Wyd. Polska Fundacja Promocji Kadr- Zarząd.

9. Fehér, J. (2015) Value Work and Leadership Practices. Gazdaság és Társadalom, 2015 (4). pp. 17-31. http://dx.doi.org/10.21637/GT.2015.4.02

10. Hurta, H., Dunay, A. (2013): Trust as a Social Capital in Hungarian Small and Medium-Sized Enterprises. In: Illés Cs B, Bylok F (eds.) People, Knowledge and Modern Technologies in the Management of Contemporary Organizations Theoretical and Practical Approaches. 320 p. Gödöllö: Szent István Egyetemi Kiadó, pp. 56-67.

11. Illés, Cs. B., Hurta, H., Dunay, A. (2015): Efficiency and Profitability Along the Lifecycle Stages of Small Enterprises. International Journal of Management 
and Enterprise Development
http://dx.doi.org/10.1504/IJMED.2015.069311

12. Jasińska, M. (2010): Outplacement jako element kształtowania postaw (Outplacement as an element of formation of attitudes). In: F. Bylok, A. Słocińska (ed.) Człowiek-praca-organizacja. Wymiary socjologiczne, psychologiczne i zarządcze (Individual-work-organization. Sociological, psychological and managerial dimensions), Wyd. Politechniki Częstochowskiej, Częstochowa.

13. Kieser A., Nagel R., Kruger K-H., Hippler G. (1990): Die Einfuhrung neuer Mitarbeitern in das Unternehmen. 2. Aufl. Hermann Luchterhand Verlag Frankfurt.

14. Kożuch, B. (2010): Przesłanki, rodzaje i narzędzia restrukturyzacji przedsiębiorstw (Premises, types and tools of restructuring of enterprises). Kraków: Zeszyty Naukowe Wyższej Szkoły Zarządzania i Bankowosci w Krakowie.

15. Lachiewicz, S., Zakrzewska-Bielawska A. (2005): Restrukturyzacja organizacji i zasobów kadrowych przedsiębiorstw (Restructuring of organization and personnel resources of enterprises). Kraków: Oficyna Wydawnicza, Kraków.

16. Małachowski, W. (2006): Outplacement jako narzędzie zarządzania zasobami ludzkimi (Outplacement as a tool in management of human resources). Kraków: Wyd. Instytut Organizacji i Zarządzania „ORGMASZ”.

17. Moerel, M. (1995) [ed.]: Zbiorowe stosunki pracy w procesie przemian (Collective Labour relations in the process of transformation). Warszawa: Wyd. IFiS PAN.

18. Nalepka, A. (1998): Zarys problematyki restrukturyzacji przedsiębiorstw (Outline of problematic issues and restructuring of enterprises). Kraków: Antykwa, Kraków.

19. Oechler, W.A. (2000): Personal und Arbeit. 7 Aufl. Verlag Oldenbourg. Munchen, Wien 2000.

20. Oleksyn, T. (2000): Restrukturyzacja zatrudnienia, „Praca i Zabezpieczenie Społeczne" (Restructuring of employment, Work and Social Security), no. 7-8, p. 2-8.

21. Pocztowski, A. (1998): Zarządzanie zasobami ludzkimi. Zarys problematyki i metod (Management of human resources. Outline of problematic issues and methods). Kraków: Wyd. Antykwa.

22. Sajkiewicz, A., Sajkiewicz, Ł. (2002): Nowe metody pracy z ludźmi. Organizacja procesów personalnych (New methods of working with people. Organization of personnel processes). Warszawa: Poltext.

23. Sztumski, J. (1999): Socjologia pracy (Sociology of work). Katowice: Wyd.Górnośląska Wyższa Szkoła Handlowa.

24. Wagner, H. (1994): Personnel management. Grundlagen der betrieblichen Personalarbeit. 3 Auflage, Münster 